\title{
Thiofaba tepidiphila gen. nov., sp. nov., a novel obligately chemolithoautotrophic, sulfur-oxidizing bacterium of the Gammaproteobacteria isolated from a hot spring
}

Correspondence

Koji Mori

mori@nbrc.nite.go.jp

\author{
Koji Mori and Ken-ichiro Suzuki
}

NITE Biological Resource Center (NBRC), National Institute of Technology and Evaluation (NITE), 2-5-8 Kazusakamatari, Kisarazu, Chiba 292-0818, Japan
In natural and artificial environments, many sulfide/ oxygen interface layers exist (e.g. hot springs, hydrothermal vents, cold seep sediments, wastewater biofilms and anaerobic zones of lakes), which are inhabited by various chemolithoautotrophic, sulfur-oxidizing micro-organisms. These chemolithoautotrophic, sulfur-oxidizing microorganisms play important roles in the sulfur cycle, as well as in the production of organic materials as primary producers. Various kinds of chemolithoautotrophic, sulfur-oxidizing micro-organisms have been detected at different sulfide concentrations, $\mathrm{pH}$ values, temperatures and under other chemical and physical conditions and they are phylogenetically widespread among the prokaryotes. Most of those identified to date belong to the phylum Proteobacteria, with other species belonging to a deep lineage in the Bacteria and the order Sulfolobales in the Archaea (Huber \& Prangishvili, 2006; La Rivière \& Schmidt, 2006; Robertson \& Kuenen, 2006; Sorokin et al., 2006; Takai et al., 2003a).

Hot springs and hydrothermal vents are major sites with a constant supply of sulfide, where large biomasses of sulfuroxidizing bacteria, called microbial mats, often develop (Elshahed et al., 2003; Reysenbach et al., 1994; Schulz et al.,

The GenBank/EMBL/DDBJ accession number for the 16S rRNA gene sequence of strain BDA453 ${ }^{\top}$ is $A B 304258$.
1999; Skirnisdottir et al., 2000; Yamamoto et al., 1998). The temperature of hot springs is very important for the community structures of microbial mats (Hiraishi et al., 1999; Skirnisdottir et al., 2000) and various thermophilic, chemolithoautotrophic, sulfur-oxidizing bacteria have been isolated from them depending on the in situ temperature, e.g. Sulfurihydrogenibium subterraneum (Takai et al., 2003b), Thermocrinis ruber (Huber et al., 1998), Thiobacter subterraneus (Hirayama et al., 2005) and Thiobacillus aquaesulis (Wood \& Kelly, 1988). Most thermophilic, chemolithoautotrophic, sulfur-oxidizing isolates belong to the orders Aquificales (Götz et al., 2002; Huber et al., 1992, 1998; Nakagawa et al., 2004; Takai et al., 2003b) and Sulfolobales (Huber \& Stetter, 1991; Segerer et al., 1986, 1991), although some strains have been reported to belong to the class Gammaproteobacteria. The only species of thermophilic (or thermotolerant), chemolithoautotrophic, sulfur-oxidizing bacteria that are known to belong to the Gammaproteobacteria are Acidithiobacillus caldus (Hallberg \& Lindström, 1994; Kelly \& Wood, 2000), Thermithiobacillus tepidarius (Kelly \& Wood, 2000; Wood \& Kelly, 1985), Thiomicrospira thermophila (Takai et al., 2004) and Sulfurivirga caldicuralii (Takai et al., 2006).

Recently, a novel moderately thermophilic, obligately chemolithoautotrophic, sulfur-oxidizing bacterium, designated 
strain $\mathrm{BDA} 453^{\mathrm{T}}$, was isolated from a hot spring in Fukushima prefecture, Japan. Based on phylogenetic analysis, this isolate has been classified in a new genus in the class Gammaproteobacteria. In this paper, a novel taxon is proposed for strain $\mathrm{BDA} 453^{\mathrm{T}}$ : Thiofaba tepidiphila gen. nov., sp. nov.

Akayu hot spring is a sulfur spring located in Fukushima prefecture, Japan. The temperature and $\mathrm{pH}$ of the water in this hot spring are $45{ }^{\circ} \mathrm{C}$ and 7.0 , respectively. In order to enrich and isolate sulfur-oxidizing bacteria, AP96SO1 medium, i.e. basal medium supplemented with $5 \mathrm{mM}$ $\mathrm{Na}_{2} \mathrm{~S}_{2} \mathrm{O}_{3}$ under an $\mathrm{N}_{2} / \mathrm{CO}_{2} / \mathrm{O}_{2}[60: 20: 20(\mathrm{v} / \mathrm{v}) ; 150 \mathrm{kPa}]$ atmosphere, was used. The basal medium was composed of the following salts and solutions $\left(\mathrm{l}^{-1}\right): 1.2 \mathrm{~g} \mathrm{KH}_{2} \mathrm{PO}_{4}, 0.2 \mathrm{~g}$ $\mathrm{K}_{2} \mathrm{HPO}_{4}, 0.75 \mathrm{~g} \mathrm{MgCl}_{2} .6 \mathrm{H}_{2} \mathrm{O}, 0.15 \mathrm{~g} \mathrm{CaCl}_{2} .2 \mathrm{H}_{2} \mathrm{O}, 0.5 \mathrm{~g}$ $\mathrm{NH}_{4} \mathrm{Cl}, 0.5 \mathrm{~g} \mathrm{Na}_{2} \mathrm{CO}_{3}, 2 \mathrm{ml}$ trace element solution of NBRC medium 377 (NBRC, 2005) and $2 \mathrm{ml}$ vitamin solution of NBRC medium 377 (NBRC, 2005). The medium was prepared in vials and bottles sealed with butyl-rubber stoppers and aluminium caps under $\mathrm{N}_{2} / \mathrm{CO}_{2} /$ $\mathrm{O}_{2}$. For primary enrichment of sulfur-oxidizing bacteria, $2 \mathrm{ml}$ hot spring water was inoculated into $20 \mathrm{ml}$ AP96SO1 medium and cultivated at $45{ }^{\circ} \mathrm{C}$. After incubation for 1 week, bacterial growth was observed in the culture microscopically and then the enrichment culture was transferred to fresh AP96SO1 medium several times. Because growth of the enriched bacteria could not be achieved successfully on solid AP96SO1 medium, an attempt was made to isolate bacteria by serial dilution using AP96SO1 medium. After repeating the maximum dilution several times, a sulfur-oxidizing bacterium, designated strain $\mathrm{BDA} 453^{\mathrm{T}}$, was obtained. The purity of the isolate was verified by microscopic observation, inoculation into the basal medium containing various heterotrophic substrates and determination of the $16 \mathrm{~S}$ rRNA gene sequence amplified using the following primer sets: universal primer set 530 f and 1392r, bacterial primer set $27 \mathrm{f}$ and 1492r (Lane, 1991) and archaeal primer set A109f (Grosskopf et al., 1998) and Arch915 (Stahl \& Amann, 1991).

Cells of strain BDA453 $3^{\mathrm{T}}$ were short rods $(0.5-0.9 \mu \mathrm{m}$ in length and $0.4 \mu \mathrm{m}$ in width) with a single polar flagellum (Fig. 1a and b). Under the microscope, they appeared as single cells, in pairs or sometimes as aggregates. Cell motility was observed, but spore formation was not. For the observation of ultrathin sections, cells were fixed with $0.1 \%(\mathrm{v} / \mathrm{v})$ glutaraldehyde and $4 \%(\mathrm{v} / \mathrm{v})$ osmium tetroxide, stained with platinum blue (Inaga et al., 2007) and lead citrate, and observed using an electron microscope (model H-7600; Hitachi) operating at $100 \mathrm{kV}$. Cells of strain $\mathrm{BDA} 453^{\mathrm{T}}$ possessed one or two inclusions like a carboxysome in the cell and a Gram-negative type of cell wall with an outer membrane (Fig. 1c). Cells were Gramnegative, catalase-negative and weakly oxidase-positive.

Cellular fatty acids were methylated by a $5 \% \mathrm{HCl} /$ methanol solution (Sasser, 1990) and analysed with the MIDI microbial identification system (Microbial ID; Agilent Technologies) and GC-MS (GC system model 6890 and MSD model 5973; Agilent Technologies). Strain BDA $453^{\mathrm{T}}$ possessed $\mathrm{C}_{18: 1} \omega 9 \mathrm{c}$ (38\% of the total fatty acids) and $\mathrm{C}_{16: 0}(34 \%)$ as major fatty acids and $\mathrm{C}_{16: 1} \omega 7 c(18 \%)$, $\mathrm{C}_{12: 0}(7 \%), \mathrm{C}_{12: 0} 3-\mathrm{OH}(2 \%)$ and $\mathrm{C}_{18: 0}(2 \%)$ as minor fatty acids. An isoprenoid quinone was extracted from the cells according to the protocol of Nakagawa \& Yamasato
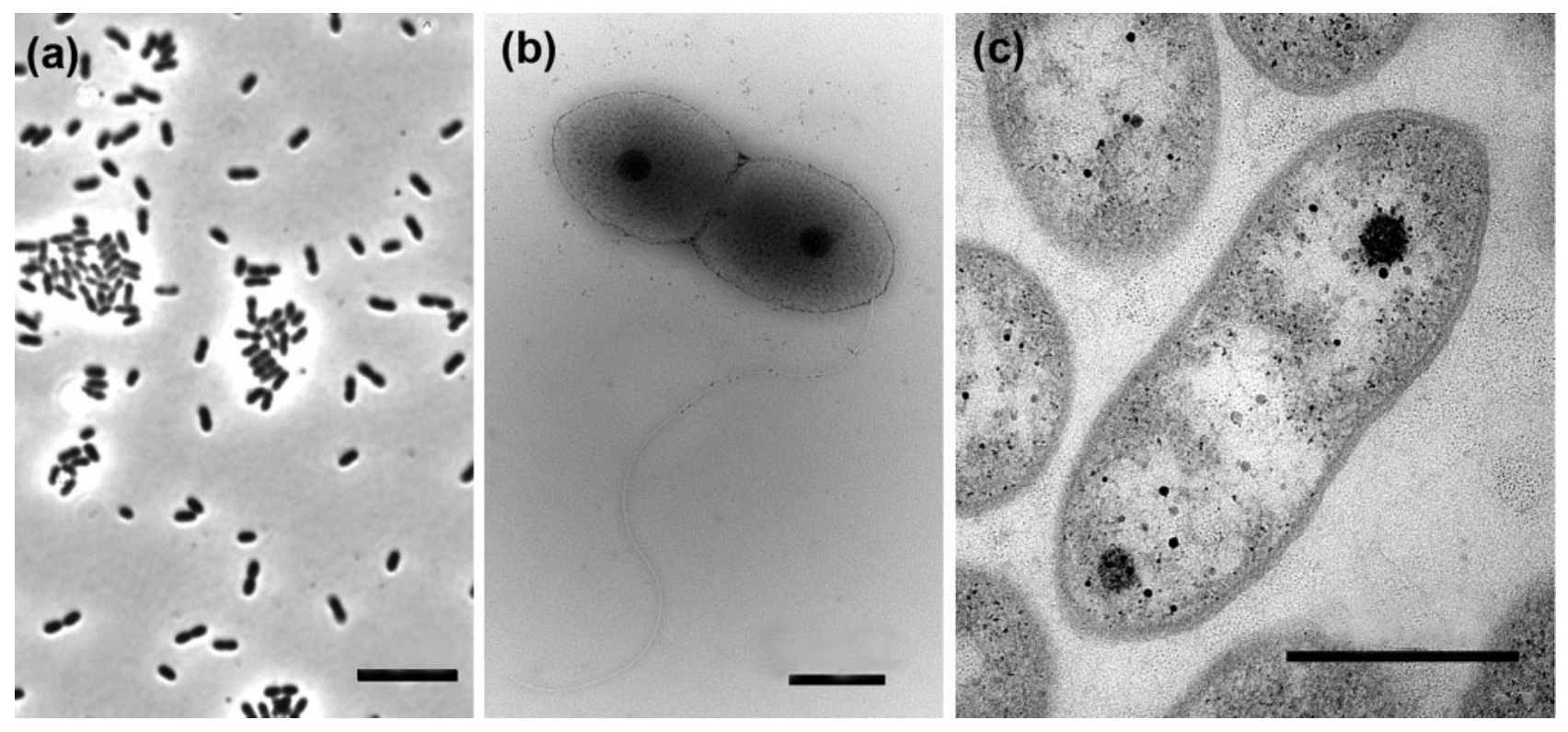

Fig. 1. Phase-contrast $\left(a ; b a r, 3 \mu \mathrm{m}\right.$ ) and transmission electron (b and $c$; bars, $0.5 \mu \mathrm{m}$ ) micrographs of strain $B D A 453^{\top}$. Negatively stained cells and ultrathin cell sections are shown in (b) and (c), respectively. 
(1993) and analysed with an LCMS-QP $8000 \alpha$ spectrometer (Shimadzu). Strain BDA $453^{\mathrm{T}}$ contained ubiquinone8. The genomic DNA $\mathrm{G}+\mathrm{C}$ content was determined by HPLC using a Shodex ODS pack F-411 (Showa Denko K.K.) after nuclease P1 treatment using a DNA-GC kit (Yamasa Shoyu) followed by alkaline phosphatase treatment (Kamagata \& Mikami, 1991). The DNA G+C content of strain $\mathrm{BDA} 453^{\mathrm{T}}$ was $66.0 \mathrm{~mol} \%$.

In the basal medium containing sulfur compounds under an $\mathrm{N}_{2} / \mathrm{CO}_{2} / \mathrm{O}_{2}$ atmosphere, strain $\mathrm{BDA} 453^{\mathrm{T}}$ oxidized thiosulfate $(5 \mathrm{mM})$, elemental sulfur $(5 \%)$, sulfide (2 and $5 \mathrm{mM}$ ) and tetrathionate (5 and $10 \mathrm{mM}$ ) as electron donors. The following substrates could not support growth of the strain: sulfite ( 2 and $5 \mathrm{mM}), \mathrm{CH}_{4}\left[\mathrm{~N}_{2} / \mathrm{CO}_{2} / \mathrm{O}_{2} / \mathrm{CH}_{4}\right.$, $50: 20: 20: 10(\mathrm{v} / \mathrm{v}) ; 150 \mathrm{kPa}], \mathrm{H}_{2}\left[\mathrm{H}_{2} / \mathrm{CO}_{2} / \mathrm{O}_{2}, 60: 20: 20\right.$ $(\mathrm{v} / \mathrm{v}) ; 150 \mathrm{kPa}], \mathrm{H}_{2}+$ acetate $(10 \mathrm{mM})$, methanol (2 and $5 \mathrm{mM})$, formate $(10$ and $30 \mathrm{mM})$, acetate $(10$ and $30 \mathrm{mM})$, butyrate $(10 \mathrm{mM})$, citrate $(10 \mathrm{mM})$, fumarate $(10 \mathrm{mM})$, glutamate $(10 \mathrm{mM})$, lactate $(10 \mathrm{mM})$, pyruvate $(10 \mathrm{mM})$, malate $(10 \mathrm{mM})$, succinate $(10 \mathrm{mM})$, L-arginine $(10 \mathrm{mM})$, L-asparagine $(10 \mathrm{mM})$, L-cysteine $(10 \mathrm{mM})$, Lhistidine $(10 \mathrm{mM})$, L-leucine $(10 \mathrm{mM})$, L-methionine $(10 \mathrm{mM})$, arabinose $(5 \mathrm{mM})$, fructose $(5 \mathrm{mM})$, galactose $(5 \mathrm{mM})$, glucose $(5 \mathrm{mM})$, inositol $(5 \mathrm{mM})$, mannose $(5 \mathrm{mM})$, raffinose $(5 \mathrm{mM})$, sucrose $(5 \mathrm{mM})$, xylose $(10 \mathrm{mM})$, Bacto yeast extract $\left(2 \mathrm{~g} \mathrm{l}^{-1}\right.$; Difco), polypeptone $\left(2 \mathrm{~g} \mathrm{l}^{-1}\right.$; Nihon Seiyaku) and Bacto Casamino acids $\left(2 \mathrm{~g} \mathrm{l}^{-1}\right.$; Difco). In the presence of thiosulfate, elemental sulfur or sulfide as an electron donor, strain $\mathrm{BDA} 453^{\mathrm{T}}$ used only oxygen as an electron acceptor. Strain BDA $453^{\mathrm{T}}$ could not grow by fermentation. Anaerobic growth with nitrate $(10 \mathrm{mM})$ and fumarate $(10 \mathrm{mM})$ was not observed. These results indicate that strain $\mathrm{BDA} 453^{\mathrm{T}}$ is an obligate chemolithoautotroph that obtains energy for growth by the oxidation of sulfur and carbon dioxide fixation.

The optimum temperature, $\mathrm{pH}$ and $\mathrm{NaCl}$ concentration ranges for growth with thiosulfate $(5 \mathrm{mM})$ and oxygen as electron donor and acceptor, respectively, were determined by examining the time-course of optical density (temperature gradient incubator with a bio-photorecorder, model TN-2612; ADVANTEC), and the decrease in the level of thiosulfate and increase in that of sulfate. The concentration of thiosulfate and sulfate were measured by HPLC (model 2695 with conductivity detector model 432 and ICPak Anion column; Waters). Strain BDA $453^{\mathrm{T}}$ was able to grow at $20-51{ }^{\circ} \mathrm{C}$, the optimum temperature being $45^{\circ} \mathrm{C}$. The initial $\mathrm{pH}$ range for growth was 6.0-9.0 and the optimum $\mathrm{pH}$ was 6.5. The $\mathrm{pH}$ in the medium decreased during the cultivation. The isolate grew optimally in the absence of $\mathrm{NaCl}$ and growth did not occur above $2 \%$ $(\mathrm{w} / \mathrm{v}) \mathrm{NaCl}$. The growth curve of strain BDA453 $3^{\mathrm{T}}$ under optimum growth conditions $\left(45^{\circ} \mathrm{C}, \mathrm{pH} 6.5\right.$ and $0 \% \mathrm{NaCl}$ concentration) is shown in Fig. 2. Strain $\mathrm{BDA} 453^{\mathrm{T}}$ grew with a doubling time of $1.64 \mathrm{~h}$ and the final concentration of the cells was approximately $1 \times 10^{6}$ cells $\mathrm{ml}^{-1}$.

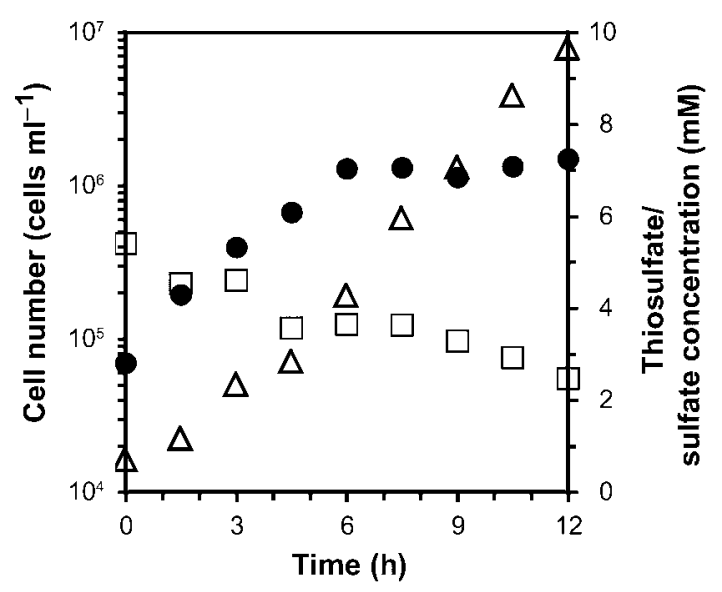

Fig. 2. Time-course of the growth of strain $B D A 453^{\top}$ and concentrations of thiosulfate and sulfate under optimum growth conditions $\left(45^{\circ} \mathrm{C}, \mathrm{pH} 6.5\right.$ and no $\mathrm{NaCl}$ ). Cell density was measured by direct counting of cells stained with $4^{\prime}, 6$-diamidino2-phenylindole on membrane filters $(0.2 \mu \mathrm{m}$ pore size polycarbonate membrane filter; ADVANTEC). ๑, Cell density; $\square$, thiosulfate concentration; $\triangle$, sulfate concentration.

An almost-complete 16S rRNA gene sequence of strain $\mathrm{BDA} 453^{\mathrm{T}}$ was determined according to the procedure reported previously by Hattori et al. (2000). After alignment with the ARB program (Ludwig et al., 2004), phylogenetic trees were constructed by the neighbourjoining method using the CLUSTAL_X program (Saitou \& Nei, 1987; Thompson et al., 1997) and the maximumlikelihood method using the NUCML program in MOLPHY (Adachi \& Hasegawa, 1995; Hasegawa et al., 1985; Mori et al., 2003). Phylogenetic analysis based on $16 \mathrm{~S}$ rRNA gene sequences revealed that strain $\mathrm{BDA} 453^{\mathrm{T}}$ belonged to the class Gammaproteobacteria. However, the sequence of strain BDA453 ${ }^{\mathrm{T}}$ was distant from those of all known genera in the Gammaproteobacteria and the similarities between strain BDA $453^{\mathrm{T}}$ and species with validly published names were less than $90 \%$. Furthermore, the sequence of strain BDA $453^{\mathrm{T}}$ resembled those of 'Thiobacillus baregensis' (sequence similarity 92.6\%; GenBank accession number Y09280) and the following environmental clones: clone MO31 from a hot spring microbial mat in India (99.7\%; EU037210); clone BPC028 from a hydrocarbon seep sediment (96.8\%; AF154088); clone MS149BH1062003_5 from the subsurface water of the Kalahari Shield, South Africa (95.5\%; DQ354745); clone zEL16 from a limestonecorroding stream biofilm in Frasassi Cave, Italy (95.1\%; DQ415810) (Macalady et al., 2006); and clone SILK74 from a sulfur-oxidizing biofilm in Frasassi Cave, Italy (95.2\%; EF467495). Phylogenetic analyses using both neighbour-joining and maximum-likelihood methods of strain $\mathrm{BDA} 453^{\mathrm{T}}$, related species in Gammaproteobacteria and related clones demonstrated that strain $\mathrm{BDA} 453^{\mathrm{T}}$ was associated with members of the family Halothiobacillaceae in the order Chromatiales, although the sequence 
similarities between strain $\mathrm{BDA} 453^{\mathrm{T}}$ and species of the genera Halothiobacillus and Thiovirga were less than $90 \%$. The tree constructed using the neighbour-joining method is shown in Fig. 3.

Characteristics of strain BDA453 $3^{\mathrm{T}}$ and members of the genera Halothiobacillus and Thiovirga are summarized in Table 1. The genus Halothiobacillus comprises obligately chemolithoautotrophic, sulfur-oxidizing bacteria (Durand et al., 1993; Hutchinson et al., 1965, 1969; Kelly et al., 1998; McDonald et al., 1997; Sievert et al., 2000; Smith \& Kelly, 1979; Visser et al., 1997; Wood \& Kelly, 1991) and can be distinguished from Thiobacillus based on halophilicity and the results of a comparison of 16S rRNA gene sequences (Kelly \& Wood, 2000). Strain BDA453 $3^{\mathrm{T}}$ preferred the absence of $\mathrm{NaCl}$ and this finding differentiated it from members of the genus Halothiobacillus. The sole species of the genus Thiovirga was isolated from wastewater biofilms (Ito et al., 2004) and described as a new genus belonging to the Halothiobacillaceae (Ito et al., 2005). Thiovirga sulfuroxydans was not halophilic and could not grow at
$\mathrm{NaCl}$ concentrations above $180 \mathrm{mM}$. Strain $\mathrm{BDA} 453^{\mathrm{T}}$ was also a non-halophilic, sulfur-oxidizing bacterium, but it clearly differed from Thiovirga sulfuroxydans with regard to the optimum growth temperature and $\mathrm{pH}$ and genomic DNA G + C content (Table 1). These phenotypic differences support the phylogenetically solitary position of strain BDA $453^{\mathrm{T}}$ in the family Halothiobacillaceae (Fig. 3). On the basis of physiological and phylogenetic findings, a novel taxon, Thiofaba tepidiphila gen. nov., sp. nov., belonging to the family Halothiobacillaceae, is proposed.

\section{Description of Thiofaba gen. nov.}

Thiofaba (Thi.o.fa'ba. Gr. n. thion sulfur; L. fem. n. faba bean; N.L. fem. n. Thiofaba sulfur bean).

Obligately aerobic and chemolithoautotrophic Gram-negative rods. Do not form spores. Grow by the oxidation of reduced sulfur compounds and the fixation of carbon dioxide. Nonhalophilic. Contain ubiquinone- 8 as a major respiratory quinone. Major cellular fatty acids are $\mathrm{C}_{18: 1} \omega 9 c$ and

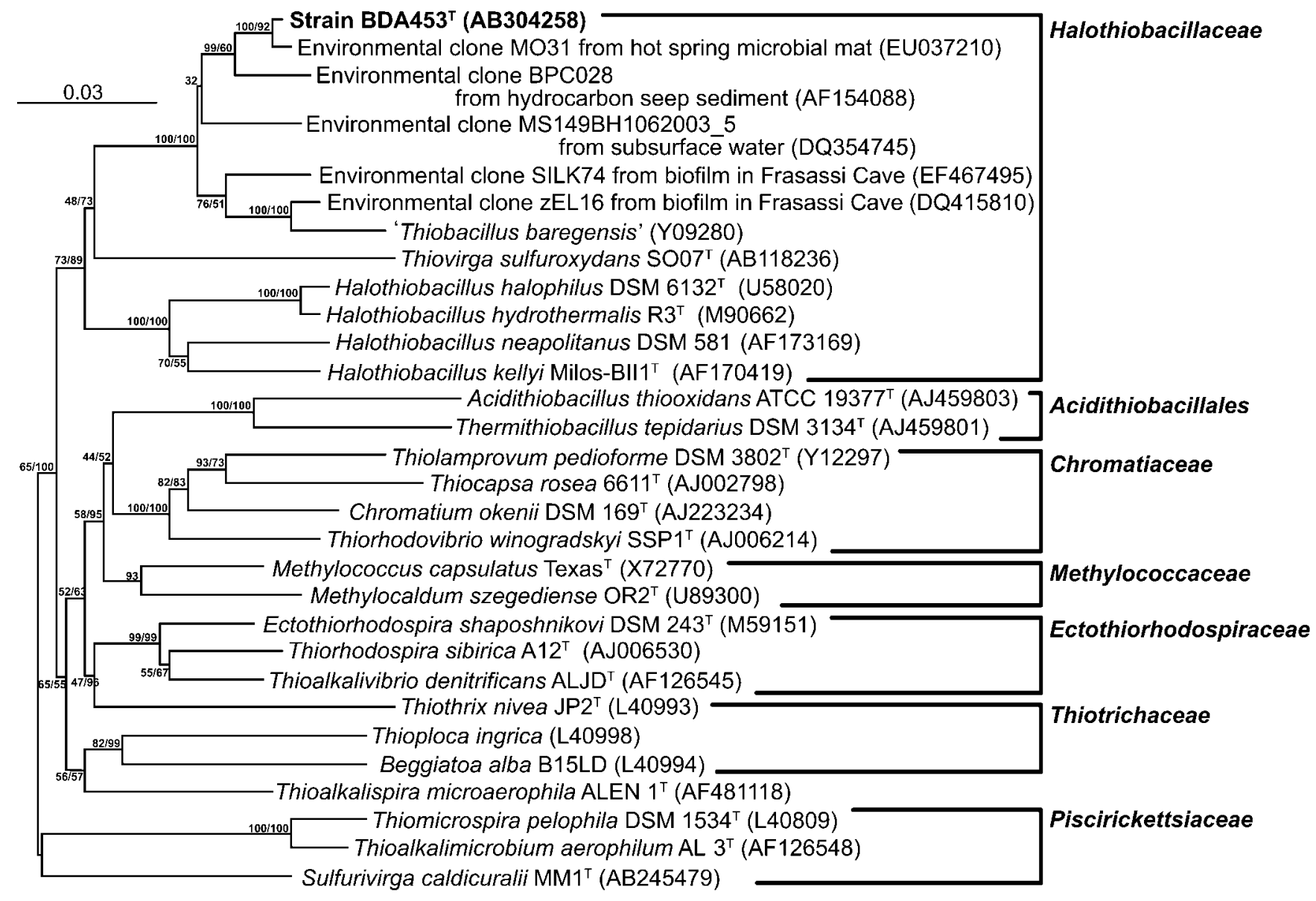

Fig. 3. Neighbour-joining tree based on $16 \mathrm{~S}$ rRNA gene sequences of strain BDA453 ${ }^{\top}$ and relatives. After alignment with the ARB program, 1075 positions were used for analyses. The numbers at the nodes represent the bootstrap values. Two numbers are indicated if identical topology was given by both trees (neighbour-joining tree/maximum-likelihood tree); a single number represents the bootstrap value calculated by the neighbour-joining method. Bar, 0.03 substitutions per nucleotide site. 
Table 1. Characteristics of strain BDA453 ${ }^{\top}$ and species of Thiovirga and Halothiobacillus

Strains: 1, T. tepidiphila BDA453 ${ }^{\mathrm{T}} ; 2$, T. sulfuroxydans SO07 ${ }^{\mathrm{T}} ; 3$, H. neapolitanus DSM 581; 4, H. halophilus DSM 6132 ${ }^{\mathrm{T}}$; 5 , H. hydrothermalis $\mathrm{R}^{\mathrm{T}}$; 6 , H. kellyi Milos-BII1 ${ }^{\mathrm{T}}$. All strains grow chemolithoautotrophically using thiosulfate, sulfur and sulfide as electron donors in the presence of oxygen, they do not use nitrate as an electron acceptor and they contain ubiquinone-8. Reference data are from Hutchinson et al. (1965, 1969), Smith \& Kelly (1979), Durand et al. (1993), Wood \& Kelly (1991), McDonald et al. (1997), Visser et al. (1997), Kelly et al. (1998), Sievert et al. (2000), Kelly \& Wood (2005) and Ito et al. (2005). ND, Not determined.

\begin{tabular}{|c|c|c|c|c|c|c|}
\hline Characteristic & 1 & 2 & 3 & 4 & 5 & 6 \\
\hline Temperature $\left({ }^{\circ} \mathrm{C}\right)$ & 45 & $30-34$ & $28-32$ & $30-32$ & $35-40$ & $37-42$ \\
\hline $\mathrm{NaCl}(\mathrm{mM})$ & 0 & 0 & $\mathrm{ND}$ & $800-1000$ & 430 & $400-500$ \\
\hline Upper $\mathrm{NaCl}$ concentration for growth (mM) & 170 & 180 & $>860$ & 4000 & 2000 & 2500 \\
\hline DNA G $+\mathrm{C}$ content $(\mathrm{mol} \%)$ & 66.0 & 47.1 & 56.0 & 64.2 & 67.4 & 62.0 \\
\hline
\end{tabular}

$\mathrm{C}_{16: 0}$. Phylogenetic position based on 16S rRNA gene sequence is in the family Halothiobacillaceae of the class Gammaproteobacteria. The type species is Thiofaba tepidiphila.

\section{Description of Thiofaba tepidiphila sp. nov.}

Thiofaba tepidiphila (te.pi.di'phi.la. L. adj. tepidus moderately warm; Gr. adj. philos loving; N.L. fem. adj. tepidiphila loving lukewarm conditions).

Cells are short rods, approximately $0.4 \mu \mathrm{m}$ wide and $0.5-$ $0.9 \mu \mathrm{m}$ long, with a single polar flagellum. Cells possess an inclusion and a Gram-negative type cell wall. Cells occur singly, in pairs or as aggregates. Motility is observed. Gram reaction is negative. Catalase-negative and weakly oxidasepositive. Obligately chemolithoautotrophic and grows aerobically by the oxidation of reduced sulfur compounds (thiosulfate, elemental sulfur, sulfide and tetrathionate) and the fixation of carbon dioxide. Anaerobic respiration and fermentation are not observed. Grows at $20-51{ }^{\circ} \mathrm{C}$; optimum growth at $45{ }^{\circ} \mathrm{C}$. The initial $\mathrm{pH}$ range for growth is 6.0-9.0, with optimum at $\mathrm{pH} 6.5 ; \mathrm{pH}$ decreases during growth. Grows optimally in the absence of $\mathrm{NaCl}$; does not grow at above $2 \%$ $(\mathrm{w} / \mathrm{v}) \mathrm{NaCl}$. Ubiquinone-8 is a major quinone. Major cellular fatty acids are $\mathrm{C}_{18: 1} \omega 9 c$ and $\mathrm{C}_{16: 0} ; \mathrm{C}_{16: 1} \omega 7 c, \mathrm{C}_{12: 0}, \mathrm{C}_{12: 0} 3-$ $\mathrm{OH}$ and $\mathrm{C}_{18: 0}$ are also present as minor components. The DNA G $+\mathrm{C}$ content of the type strain is $66.0 \mathrm{~mol} \%$.

The type strain, BDA453 ${ }^{\mathrm{T}} \quad$ (=NBRC $103218^{\mathrm{T}}=\mathrm{DSM}$ $19618^{\mathrm{T}}$ ), was isolated from water of a hot spring, Akayu, Fukushima Prefecture, Japan.

\section{Acknowledgements}

We thank Ms Kuniko Shimamura for technical support. We also thank Dr Kenji Tanaka and Ms Kaoru Yamaguchi for electronmicroscopic observation.

\section{References}

Adachi, J. \& Hasegawa, M. (1995). Improved dating of the human/ chimpanzee separation in the mitochondrial DNA tree: heterogeneity among amino acid sites. J Mol Evol 40, 622-628.
Durand, P., Reysenbach, A. L., Prieur, D. \& Pace, N. (1993). Isolation and characterization of Thiobacillus hydrothermalis sp. nov., a mesophilic obligately chemolithoautotrophic bacterium isolated from a deep-sea hydrothermal vent in Fiji Basin. Arch Microbiol 159, 39-44.

Elshahed, M. S., Senko, J. M., Najar, F. Z., Kenton, S. M., Roe, B. A., Dewers, T. A., Spear, J. R. \& Krumholz, L. R. (2003). Bacterial diversity and sulfur cycling in a mesophilic sulfide-rich spring. Appl Environ Microbiol 69, 5609-5621.

Götz, D., Banta, A., Beveridge, T. J., Rushdi, A. I., Simoneit, B. R. \& Reysenbach, A. L. (2002). Persephonella marina gen. nov., sp. nov. and Persephonella guaymasensis sp. nov., two novel, thermophilic, hydrogen-oxidizing microaerophiles from deep-sea hydrothermal vents. Int J Syst Evol Microbiol 52, 1349-1359.

Grosskopf, R., Janssen, P. H. \& Liesack, W. (1998). Diversity and structure of the methanogenic community in anoxic rice paddy soil microcosms as examined by cultivation and direct 16S rRNA gene sequence retrieval. Appl Environ Microbiol 64, 960-969.

Hallberg, K. B. \& Lindström, E. B. (1994). Characterization of Thiobacillus caldus sp. nov., a moderately thermophilic acidophile. Microbiology 140, 3451-3456.

Hasegawa, M., Kishino, H. \& Yano, T. (1985). Dating of the humanape splitting by a molecular clock of mitochondrial DNA. J Mol Evol 22, 160-174.

Hattori, S., Kamagata, Y., Hanada, S. \& Shoun, H. (2000). Thermacetogenium phaeum gen. nov., sp. nov., a strictly anaerobic, thermophilic, syntrophic acetate-oxidizing bacterium. Int J Syst Evol Microbiol 50, 1601-1609.

Hiraishi, A., Umezawa, T., Yamamoto, H., Kato, K. \& Maki, Y. (1999). Changes in quinone profiles of hot spring microbial mats with a thermal gradient. Appl Environ Microbiol 65, 198-205.

Hirayama, H., Takai, K., Inagaki, F., Nealson, K. H. \& Horikoshi, K. (2005). Thiobacter subterraneus gen. nov., sp. nov., an obligately chemolithoautotrophic, thermophilic, sulfur-oxidizing bacterium from a subsurface hot aquifer. Int J Syst Evol Microbiol 55, 467-472.

Huber, H. \& Prangishvili, D. (2006). Sulfolobales. In The Prokaryotes. A Handbook on the Biology of Bacteria, 3rd edn, vol. 3, pp. 23-51. Edited by M. Dworkin, S. Falkow, E. Rosenberg, K.-H. Schleifer \& E. Stackebrandt. New York: Springer.

Huber, G. \& Stetter, K. O. (1991). Sulfolobus metallicus, sp. nov., a novel strictly chemolithoautotrophic thermophilic archaeal species of metal-mobilizers. Syst Appl Microbiol 14, 372-378.

Huber, R., Wilharm, T., Huber, D., Trincone, A., Burggraf, S., König, H., Rachel, R., Rockinger, l., Fricke, H. \& Stetter, K. O. (1992). Aquifex pyrophilus gen. nov., sp. nov., represents a novel 
group of marine hyperthermophilic hydrogen-oxidizing bacteria. Syst Appl Microbiol 15, 340-351.

Huber, R., Eder, W., Heldwein, S., Wanner, G., Huber, H., Rachel, R. \& Stetter, K. O. (1998). Thermocrinis ruber gen. nov., sp. nov., a pinkfilament-forming hyperthermophilic bacterium isolated from Yellowstone National Park. Appl Environ Microbiol 64, 3576-3583.

Hutchinson, M., Johnstone, K. I. \& White, D. (1965). The taxonomy of certain thiobacilli. J Gen Microbiol 41, 357-366.

Hutchinson, M., Johnstone, K. I. \& White, D. (1969). Taxonomy of the genus Thiobacillus: the outcome of numerical taxonomy applied to the group as a whole. J Gen Microbiol 57, 397-410.

Inaga, S., Katsumoto, T., Tanaka, K., Kameie, T., Nakane, H. \& Naguro, T. (2007). Platinum blue as an alternative to uranyl acetate for staining in transmission electron microscopy. Arch Histol Cytol 70, 43-49.

Ito, T., Sugita, K. \& Okabe, S. (2004). Isolation, characterization, and in situ detection of a novel chemolithoautotrophic sulfur-oxidizing bacterium in wastewater biofilms growing under microaerophilic conditions. Appl Environ Microbiol 70, 3122-3129.

Ito, T., Sugita, K., Yumoto, I., Nodasaka, Y. \& Okabe, S. (2005). Thiovirga sulfuroxydans gen. nov., sp. nov., a chemolithoautotrophic sulfur-oxidizing bacterium isolated from a microaerobic waste-water biofilm. Int J Syst Evol Microbiol 55, 1059-1064.

Kamagata, Y. \& Mikami, E. (1991). Isolation and characterization of a novel thermophilic Methanosaeta strain. Int $J$ Syst Bacteriol 41, 191-196.

Kelly, D. P. \& Wood, A. P. (2000). Reclassification of some species of Thiobacillus to the newly designated genera Acidithiobacillus gen. nov., Halothiobacillus gen. nov. and Thermithiobacillus gen. nov. Int J Syst Evol Microbiol 50, 511-516.

Kelly, D. P. \& Wood, A. P. (2005). Family III. Halothiobacillaceae fam. nov. Kelly and Wood 2003. In Bergey's Manual of Systematic Bacteriology, vol. 2, pp. 58-59. Edited by D. J. Brenner, N. R. Krieg, J. T. Staley \& G. M. Garrity. New York: Springer.

Kelly, D. P., Stackebrandt, E., Burghardt, J. \& Wood, A. P. (1998). Confirmation that Thiobacillus halophilus and Thiobacillus hydrothermalis are distinct species within the gamma-subclass of the Proteobacteria. Arch Microbiol 170, 138-140.

Lane, D. J. (1991). 16S/23S rRNA sequencing. In Nucleic Acid Techniques in Bacterial Systematics, pp. 115-175. Edited by E. Stackebrandt \& M. Goodfellow. Chichester: Wiley.

La Rivière, J. W. M. \& Schmidt, K. (2006). Morphologically conspicuous sulfur-oxidizing eubacteria. In The Prokaryotes, vol. 7, pp. 941-954. Edited by M. Dworkin, S. Falkow, E. Rosenberg, K.-H. Schleifer \& E. Stackebrandt. New York: Springer.

Ludwig, W., Strunk, O., Westram, R., Richter, L., Meier, H., Yadhukumar, Buchner, A., Lai, T., Steppi, S. \& other authors (2004). ARB: a software environment for sequence data. Nucleic Acids Res 32, 1363-1371.

Macalady, J. L., Lyon, E. H., Koffman, B., Albertson, L. K., Meyer, K., Galdenzi, S. \& Mariani, S. (2006). Dominant microbial populations in limestone-corroding stream biofilms, Frasassi cave system, Italy. Appl Environ Microbiol 72, 5596-5609.

McDonald, I. R., Kelly, D. P., Murrell, J. C. \& Wood, A. P. (1997). Taxonomic relationships of Thiobacillus halophilus, Thiobacillus aquesulis, and other species of Thiobacillus, as determined using $16 \mathrm{~S}$ rRNA sequencing. Arch Microbiol 166, 394-398.

Mori, K., Kim, H., Kakegawa, T. \& Hanada, S. (2003). A novel lineage of sulfate-reducing microorganisms: Thermodesulfobiaceae fam. nov., Thermodesulfobium narugense, gen. nov., sp. nov., a new thermophilic isolate from a hot spring. Extremophiles 7, 283-290.
Nakagawa, Y. \& Yamasato, K. (1993). Phylogenetic diversity of the genus Cytophaga revealed by $16 \mathrm{~S}$ rRNA sequencing and menaquinone analysis. J Gen Microbiol 139, 1155-1161.

Nakagawa, S., Nakamura, S., Inagaki, F., Takai, K., Shirai, N. \& Sako, Y. (2004). Hydrogenivirga caldilitoris gen. nov., sp. nov., a novel extremely thermophilic, hydrogen- and sulfur-oxidizing bacterium from a coastal hydrothermal field. Int J Syst Evol Microbiol 54, 2079-2084.

NBRC (2005). NBRC Catalogue of Biological Resources: Microorganisms, Genomic DNA Clones, and cDNAs, 1st edn. Chiba, Japan: National Institute of Technology and Evaluation (NITE).

Reysenbach, A. L., Wickham, G. S. \& Pace, N. R. (1994). Phylogenetic analysis of the hyperthermophilic pink filament community in Octopus Spring, Yellowstone National Park. Appl Environ Microbiol 60, 2113-2119.

Robertson, L. \& Kuenen, J. (2006). The genus Thiobacillus. In The Prokaryotes, 3rd edn, vol. 5, pp. 812-827. Edited by M. Dworkin, S. Falkow, E. Rosenberg, K.-H. Schleifer \& E. Stackebrandt. New York: Springer.

Saitou, N. \& Nei, M. (1987). The neighbor-joining method: a new method for reconstructing phylogenetic trees. Mol Biol Evol 4, 406-425.

Sasser, M. (1990). Identification of bacteria by gas chromatography of cellular fatty acids, MIDI Technical Note 101. Newark, DE: MIDI Inc.

Schulz, H. N., Brinkhoff, T., Ferdelman, T. G., Mariné, M. H., Teske, A. \& Jørgensen, B. B. (1999). Dense populations of a giant sulfur bacterium in Namibian shelf sediments. Science 284, 493-495.

Segerer, A., Neuner, A., Kristjansson, J. K. \& Stetter, K. O. (1986). Acidianus infernus gen. nov., sp. nov., and Acidianus brierleyi comb. nov.: facultatively aerobic, extremely acidophilic thermophilic sulfurmetabolizing archaebacteria. Int J Syst Bacteriol 36, 559-564.

Segerer, A. H., Trincone, A., Gahrtz, M. \& Stetter, K. O. (1991). Stygiolobus azoricus gen. nov., sp. nov. represents a novel genus of anaerobic, extremely thermoacidophilic archaebacteria of the order Sulfolobales. Int J Syst Bacteriol 41, 495-501.

Sievert, S. M., Heidorn, T. \& Kuever, J. (2000). Halothiobacillus kellyi sp. nov., a mesophilic, obligately chemolithoautotrophic, sulfuroxidizing bacterium isolated from a shallow-water hydrothermal vent in the Aegean Sea, and emended description of the genus Halothiobacillus. Int J Syst Evol Microbiol 50, 1229-1237.

Skirnisdottir, S., Hreggvidsson, G. O., Hjörleifsdottir, S., Marteinsson, V. T., Petursdottir, S. K., Holst, O. \& Kristjansson, J. K. (2000). Influence of sulfide and temperature on species composition and community structure of hot spring microbial mats. Appl Environ Microbiol 66, 2835-2841.

Smith, A. L. \& Kelly, D. P. (1979). Competition in the chemostat between an obligately and a facultatively chemolithotrophic Thiobacillus. J Gen Microbiol 115, 377-384.

Sorokin, D. Yu., Banciu, H., Robertson, L. A. \& Kuenen, J. G. (2006). Haloalkaliphilic sulfur-oxidizing bacteria. In The Prokaryotes, 3rd edn, vol. 2, pp. 969-984. Edited by M. Dworkin, S. Falkow, E. Rosenberg, K.-H. Schleifer \& E. Stackebrandt. New York: Springer.

Stahl, D. A. \& Amann, R. (1991). Development and application of nucleic acid probes in bacterial systematics. In Nucleic Acid Techniques in Bacterial Systematics, pp. 205-248. Edited by E. Stackebrandt \& M. Goodfellow. Chichester: Wiley.

Takai, K., Inagaki, F., Nakagawa, S., Hirayama, H., Nunoura, T., Sako, Y., Nealson, K. H. \& Horikoshi, K. (2003a). Isolation and phylogenetic diversity of members of previously uncultivated epsilonProteobacteria in deep-sea hydrothermal fields. FEMS Microbiol Lett 218, 167-174. 
Takai, K., Kobayashi, H., Nealson, K. H. \& Horikoshi, K. (2003b). Sulfurihydrogenibium subterraneum gen. nov., sp. nov., from a subsurface hot aquifer. Int J Syst Evol Microbiol 53, 823-827.

Takai, K., Hirayama, H., Nakagawa, T., Suzuki, Y., Nealson, K. H. \& Horikoshi, K. (2004). Thiomicrospira thermophila sp. nov., a novel microaerobic, thermotolerant, sulfur-oxidizing chemolithomixotroph isolated from a deep-sea hydrothermal fumarole in the TOTO caldera, Mariana Arc, Western Pacific. Int J Syst Evol Microbiol 54, 2325-2333.

Takai, K., Miyazaki, M., Nunoura, T., Hirayama, H., Oida, H., Furushima, Y., Yamamoto, H. \& Horikoshi, K. (2006). Sulfurivirga caldicuralii gen. nov., sp. nov., a novel microaerobic, thermophilic, thiosulfate-oxidizing chemolithoautotroph, isolated from a shallow marine hydrothermal system occurring in a coral reef, Japan. Int J Syst Evol Microbiol 56, 1921-1929.

Thompson, J. D., Gibson, T. J., Plewniak, F., Jeanmougin, F. \& Higgins, D. G. (1997). The CLUSTAL_X windows interface: flexible strategies for multiple sequence alignment aided by quality analysis tools. Nucleic Acids Res 25, 4876-4882.
Visser, J. M., Stefess, G. C., Robertson, L. A. \& Kuenen, J. G. (1997). Thiobacillus sp. W5, the dominant autotroph oxidizing sulfide to sulfur in a reactor for aerobic treatment of sulfidic wastes. Antonie Van Leeuwenhoek 72, 127-134.

Wood, A. P. \& Kelly, D. P. (1985). Physiological characteristics of a new thermophilic obligately chemolithotrophic Thiobacillus species, Thiobacillus tepidarius. Int J Syst Bacteriol 35, 434-437.

Wood, A. P. \& Kelly, D. P. (1988). Isolation and characterisation of Thiobacillus aquaesulis sp. nov., a novel facultatively autotrophic moderate thermophile. Arch Microbiol 149, 339-343.

Wood, A. P. \& Kelly, D. P. (1991). Isolation and characterisation of Thiobacillus halophilus sp. nov., a sulfur-oxidising autotrophic eubacterium from a Western Australian hypersaline lake. Arch Microbiol 156, 277-280.

Yamamoto, H., Hiraishi, A., Kato, K., Chiura, H. X., Maki, Y. \& Shimizu, A. (1998). Phylogenetic evidence for the existence of novel thermophilic bacteria in hot spring sulfur-turf microbial mats in Japan. Appl Environ Microbiol 64, 1680-1687. 